\title{
Implementasi Metode Pembelajaran Berbasis Masalah Pada Pembelajaran Tema 2 "Selalu Berhemat Energi" Kelas Iv Peserta Didik MIN 2 Kediri
}

\author{
Farah Diba \\ Pascasarjana Institut Agama Islam Tribakti Kediri \\ jawahirkasafani@gmail.com
}

\begin{abstract}
The background of this research is: to attract students in theme learning, there needs to be a fun learning method. Therefore, problem based learning methods is selected. Researchers chose the PBL because this approach uses a learning step by steps that define problems, diagnose problems, formulate alternative strategies, define and implement preferred strategies and evaluations. The focus of this research is: (1) Implementation of problembased Learning method (problem-Based learn) in theme 2 Always save energy learners class IV D MIN 2 Kediri (2) supporting factors in implementing learning methods Problem-based Learning Methods (IVD MIN 2 Kediri Class). While the purpose of this research is: (1) to describe the implementation of problem-based learning method in theme 2 "Always save energy. 2 To describe supporting factors in implementing a problem-based learning method. The research uses a qualitative approach using class action research $(P T K)$. A qualitative approach is chosen, because with this research, it is hoped that we can collect the data obtained, then process, analyses and symbolize it, so that there is a clear understanding of the effectiveness of the method Problem-based learning in theme learning. Data collection is done by conducting observations, interviews, and documentation. Then data in analysis using data analysis is data reduction, data presentation and conclusion results. The results of the study are: (1) there is a success indicator of the successful learning percentage of the pre-action which is only $65.71 \%$ with an average value of 71.8. (2) On the complete learning to be 71.42 with a flat average of 74.9 , so there is an increase of $5.71 \%$ (3) in the cycle II the satisfaction of learning reaches $88.57 \%$ with the average value of class 80.7 and there is an increase of cycle I and cycle II as much as 17.15. (4) With this can be seen the increase of the membership of the class as much as $22.86 \%$ from the activities of pre-action until cycle II already met the success indicator is amounting to more than $75 \%$ of the number of learners.
\end{abstract}

Keywords: Problem-Based Learning Methods, Thematic Learning

\begin{abstract}
Abstrak
Latar belakang penelitian ini adalah: Untuk menarik minat siswa dalam pembelajaran tema perlu adanya metode pembelajaran yang menyenangkan. Oleh karena itu dipilih metode pembelajaran berbasis masalah (Problem Based learning methods). Peneliti memilih PBL karena pendekatan ini menggunakan
\end{abstract}


langkah langkah pembelajaran yaitu mendefinisikan masalah, mendiagnosis masalah,merumuskan alternative strategi, menentukan dan menerapkan strategi pilihan dan melakukan evaluasi. Yang menjadi fokus penelitian ini adalah : (1)Implementasi Metode Pembelajaraan Berbasis Masalah (Problem Based Learning) pada tema 2 Selalu Berhemat Energi peserta didik kelas IV D MIN 2 Kediri (2) Faktor pendukung dalam melaksanakan metode Pembelajaran Berbasis masalah (Problem Based Learning Methods) di kelas IVD MIN 2 Kediri. Sedangkan tujuan penelitian ini adalah : (1)Untuk mendeskripsikan implementasi Metode Pembelajaran Berbasis Masalah pada tema 2 "Selalu Berhemat Energi.(2)Untuk mendeskripsikan faktor pendukung dalam melaksanakan Metode Pembelajaran Berbasis masalah. Penelitian ini menggunakan pendekatan kualitatif dengan menggunakan Penelitian Tindakan Kelas (PTK). Pendekatan kualitatif dipilih, karena dengan adanya penelitian ini, diharapkan dapat mengumpulkan data-data yang diperoleh, kemudian mengolah, menganalisis dan menyimpulkannya, sehingga didapatkan pemahaman yang jelas tentang efektivitas metode Pembelajaran Berbasis Masalah dalam pembelajaran tema. Hasil penelitian adalah : (1) terdapat indikator keberhasilan presentase ketuntasan belajar dari pra tindakan yang hanya $65,71 \%$ dengan rata rata nilai 71,8 . (2) Pada sikuls I ketuntasan belajar menjadi 71,42 dengan rata rata 74,9 , jadi ada peningkatan sebanyak 5,71\% (3) Pada Siklus II ketuntasan belajar mencapai 88,57\% dengan nilai rata-rata kelas 80,7 dan ada peningkatan dari siklus I dan siklus II sebanyak 17,15. (4) Dengan ini dapat dilihat terjadinya peningkatan ketuntasan kelas sebanyak 22,86\% Dari kegiatan pra tindakan sampai siklus II sudah memenuhi indicator keberhasilan yaitu sebesar lebih dari $75 \%$ jumlah peserta didik.

\section{Kata Kunci: Metode Pembelajaran Berbasis Masalah, Pembelajaran Tematik}

\section{Pendahuluan}

Hampir empat dasarwarsa terakhir, Pemerintah Indonesia melalui Kementerian Pendidikan Nasional dan Kebudayaan (Kemendikbud) mengeluarkan berbagai macam kebijakan dalam sistem pendidikan nasional guna mencapai mutu pendidikan. Berbicara mutu bukan hanya hasil yang diperoleh peserta didik setelah mengikuti serangkaian kegiatan pembelajaran.

${ }^{1}$ Ace Suryadi, dan Dasim Budimansyah, Paradigma Pembangunan Pendidikan Nasional : Konsep, Teori dan Aplikasi dalam Analisis Kebijakan tetapi berkaitan dengan berbagai macam dimensi pendidikan yang terkait diantara satu dan lainnya. Secara konseptual mutu pendidikan dapat diartikan sebagai "kemampuan lembaga pendidikan dalam mendayagunakan berbagai macam potensi atau sumber pendidikan untuk meningkatkan kemampuan belajar seoptimal mungkin". ${ }^{1}$ Jika mutu pendidikan mengarah pada ketercapaian proses pembelajaran yang mendorong

Publik, (Bandung: Widya Aksara Pers, 2009). h. 197 

yang diharapkan yakni adanya perubahan atau kompetensi dalam diri peserta didik setelah mengikuti pembelajaran.

Pendidikan merupakan sarana terpenting untuk mewujudkan kemajuan bangsa dan negara. ${ }^{2}$ Hal ini karena pendidikan merupakan proses budaya yang bertujuan untuk meningkatkan harkat dan martabat manusia. Dengan pendidikan yang bermutu, akan tercipta sumber daya manusia yang berkualitas. Pendidikan itu sendiri berlaku seumur hidup dan dilakukan dalam lingkungan, keluarga, pendidikan formal (sekolah) dan masyarakat.Untuk itu, pendidikan merupakan tanggung jawab bersama antara keluarga, masyarakat, dan Negara.

Proses pendidikan berujung kepada pembentukan sikap, pengembangan pengembangan keterampilan anak sesuai dengan kompetensi yang dibutuhkan. Menurut Sanjaya guru merupakan pendorong belajar siswa yang mempunyai peranan besar dalam menumbuhkan semangat para murid untuk belajar. Dengan menggunakan model pembelajaran yang menarik maka siswa akan lebih mudah dalam memahami pelajaran dan mengembangkan ilmu pengetahuannya.

Kurikulum 2013 (K-13) adalah kurikulum yang berlaku dalam Sistem peserta didik untuk belajar, maka hasil kecerdasan atau intelektual, serta

Pendidikan Indonesia. Kurikulum ini merupakan kurikulum tetap diterapkan oleh pemerintah untuk menggantikan Kurikulum-2006 (yang sering disebut sebagai Kurikulum Tingkat Satuan Pendidikan) yang telah berlaku selama kurang lebih 6 tahun. Kurikulum 2013 masuk dalam masa percobaanya pada tahun 2013 dengan menjadikan beberapa sekolah menjadi sekolah rintisan.

Kurikulum 2013 memiliki empat aspek penilaian, yaitu aspek pengetahuan, aspek keterampilan, aspek sikap, dan perilaku. Di dalam Kurikulum 2013, terutama di dalam materi pembelajaran terdapat materi yang dirampingkan dan materi yang ditambahkan. ${ }^{3}$

Pelaksanaan K-13 di beberapa sekolah mengalami beberapa kendala dan permasalahan, antara lain : sulitnya mengubah mindset guru, perubahan proses pembelajaran dari teacher centered ke student centered, rendahnya moral spiritual, budaya membaca dan meneliti masih rendah, kurangnya penguasaan IT Oleh guru, lemahnya penguasaan bidang administrasi, kecenderungan guru yang lebih banyak menekankan aspek kognitif, Pembelajaran yang masih konvensional yakni para siswa hanya bisa mendengar dan melihat bagaimana guru menjelaskan suatu tema tertentu dan siswa terbiasa selalu menerima penjelasan guru. ${ }^{4}$

Peserta didik., (Yogyakarta: Deepublish, 2017), h, 29

4 Min Liu. (2005) Motivating Students Ruzz Media,2016), h. 117

3 Darmadi, Pengembangan Model dan Metode Pembelajaran dalam Dinamika Belajar Jurnal Intelektual: Jurnal Pendidikan dan Studi Keislaman Volume 9, Nomor 1, April 2019 
Ketika mereka ditanya apakah ada yang belum dimengerti mereka hanya diam, diam karena sudah paham atau diam karena takut bertanya,ketersediaan sarana dan prasarana dalam aktivitas pembelajaran dan pengelolaan proses pembelajaran, pemahaman siswa tentang pembelajaran tematik yang membosankan, kurang tepatnya model pembelajaran yang diterapkan diduga menyebabkan hasil belajar siswa rendah. Berbagai macam permasalah pelaksanaan kurikulum 2013 ini juga terjadi di MIN 2 Kediri.

Permasalah tersebut dapat teratasi salah satunya dengan mengadakan terobosan dalam pembelajaran sehingga tidak menyajikan materi yang bersifat abstrak tetapi juga harus melibatkan siswa secara aktif dalam pembelajaran. Untuk meningkatkan aktifitas belajar siswa, guru harus dapat memilih dan menyajikan strategis dan pendekatan belajar yang efektif. Berbagai macam model pembelajaran digulirkan untuk meningkatkan prestasi belajar siswa, salah satunya dengan menggunakan Model Problem Based Learning (yang selanjutnya disebut PBL).

Dalam pembelajaran model PBL ini terdapat tahapan-tahapan dalam pelaksanaannya salah satunya adalah diskusi kelompok di mana siswa harus beraktifitas di dalam kelompok tersebut seperti mengeluarkan pendapat, memecahkan soal dan menjadi tutor sebaya. Model pembelajaran PBL ini secara efektif akan membantu meningkatkan aktifitas belajar siswa karena mengharuskan siswa untuk aktif dalam tahapan diskusi kelompok. Dengan kegiatan ini diharapkan aktitas belajar siswa akan meningkat dan berdampak pada peningkatan hasil belajar siswa.

Pembelajaran Model Problem Based Learning sesuai dengan Kurikulum 2013 yang didesain untuk memenuhi tuntutan proses pembelajaran pada abad ke-21. Pembelajaran ini menggunakan sistem pembelajaran tematik terpadu dengan pendekatan yang bersifat saintific (ilmiah). Model Problem Based Learning merupakan salah satu metode pembelajaran yang layak dikembangkan seiring dengan tuntutan pembelajaran dalam penerapan Kurikulum 2013. Karakteristik dari model PBL ini juga mampu mengembangkan kemampuan berpikir kritis peserta didik. Hal ini dikarenakan dalam penggunaan model pembelajaran problem based learning menggunakan permasalahan sebagai bahan diskusi pembelajaran. Permasalahan tersebut akan dipecahkan oleh peserta didik.

\section{Metode}

Jenis penelitian dalam Penelitian Tindakan Kelas ( classroom action research $)^{5}$ penelitian kualitatif, sebab itu pendekatan yang dilakukan adalah melalui pendekatan deskriptif kualitatif. 
Maksudnya adalah dalam kualitatif data yang dikumpulkan bukan berupa angkaangka melainkan data tersebut mungkin berasal dari wawancara, catatan lapangan, dokumen pribadi, catatan Sehingga yang menjadi tujuan penelitian kualitatif adalah ingin menggambarkan realitas empirik di balik fenomena yang ada secara mendalam, rinci dan tuntas.

Lebih lanjut Sugiyono menjelaskan tentang metode penelitian pendidikan kualitatif sebagai berikut: "Metode penelitian kualitatif adalah metode penelitian yang berlandasan pada filsafat postpositivisme, digunakan unuk meneliti pada kondisi obyek alamiah, dimana peneliti adalah sebagai instrumen kunci, pengambilan sampel sumber data dilakukan secara purposive dan snowbaal, teknik pengumpulan dengan triangulasi (gabungan), analisis data bersifat induktif/ kualitatif, dan hasil penelitian kualitatif lebih menekankan makna daripada generalisasi."7 Sedangkan penelitian deskriptif ialah penelitian yang berusaha mendeskripsikan suatu gejala, peristiwa, kejadian yang terjadi saat sekarang. Penelitian deskriptif memusatkan perhatian kepada masalahmasalah aktual sebagaimana adanya pada saat penelitian berlangsung. Penelitian deskriptif hanya mengumpulmemo, dan dokumen resmi lainnya. ${ }^{6}$

kan data untuk menggambarkan fenomena yang terjadi. ${ }^{8}$

\section{Kajian Pustaka}

\section{Pengertian Pembelajaran Tematik}

Secara sederhana, istilah pembelajaran (instruction) bermakna sebagai upaya untuk membelajarkan seseorang atau kelompok orang melalui berbagai upaya (effort) dan berbagai strategi, metode, dan pendekatan ke arah pencapaian tujuan yang telah direncanakan. ${ }^{9}$ Berdasarkan UndangUndang Republik Indonesia (UU RI) tentang Sistem Pendidikan Nasional No.20 tahun 2003 pembelajaran adalah proses interaksi peserta didik dengan pendidik dan sumber belajar pada suatu lingkungan belajar. Dalam pengertian tersebut mengandung penjelasan bahwa adanya komunikasi dan kerjasama antara peserta didik dan guru untuk menambah pemahaman dan pengetahuan dengan memanfaatkan media/sarana belajar dalam proses pembelajaran. Menurut Sugihartono pembelajaran merupakan suatu upaya yang dilakukan secara sengaja oleh pendidik untuk menyampaikan ilmu pengetahuan, mengorganisai dan menciptakan sistem lingkungan dengan berbagai metode sehingga peserta didik dapat melakukan

6 Lexi J. Moleong. Metodologi Penelitian Kualitatif (Bandung : Remaja Rosdakarya, 2014), h. 5-6.

7 Sugiyono, Metode Penelitian Pendidikan Pendekatan Kuantitatif, Kualitatif, dan RED, (Bandung: Alfabeta,2013) h.15
8 Suharsimi Arikunto, Prosedur Penelitian Suatu Pendekatan Praktik. (Jakarta: Rineka Cipta, 2010) h. 131

9 Abdul Majid, Starategi Pembelajaran, (Bandung: PT Remaja Rosdakarya, 2013), h.4 
kegiatan belajar secara efektif dan efisien serta dengan hasil optimal. 10

Menurut Huda menjelaskan bahwa pembelajaran merupakan fenomena kompleks yang dipengaruhi oleh banyak faktor yang menyebabkan terjadinya suatu rekonstruksi pengalaman masa lalu sehingga mempengaruhi perilaku serta kapasitas seseorang atau kelompok. Pembelajaran merupakan proses utama yang diselenggarakan dalam kehidupan sekolah. ${ }^{11}$

Di dalam pembelajaran mempunyai beberapa hakikat. menurut Suprihatiningrum hakikat pembelajaran diantaranya adalah: ${ }^{12}$

a. Terjadinya pembelajaran dikarenakan adanya interaksi aktif antara peserta didik dengan pendidik dan lingkungan.

b. Agar proses pembelajaran berlangsung efektif dan efisien maka diperlukan suatu strategi, model dan media pembelajaran yang sesuai.

c. Pelaksanaan pembelajaran dilakukan sesuai dengan rencana yang telah ditentukan

d. Adanya perkembangan materi pembelajaran dan cara penyampaian agar peserta didik lebih mudah menerima pembelajaran.

e. Aspek yang harus diperhatikan dalam pembelajaran adalah aspek proses dan aspek hasil belajar.
Berdasarkan dari beberapa uraian diatas maka dapat disimpulkan bahwa pembelajaran adalah suatu proses interaksi antara pendidik dengan peserta didik yang terdapat didalam pendidikan untuk menciptakan kondisi belajar yang baik dengan dipengaruhi oleh beberapa komponen guna mencapai tujuan yang diinginkan. Proses pembelajaran sangatlah berpengaruh terhadap tujuan pembelajaran. Apabila proses pembelajaran berjalan dengan baik maka tujuan pembelajaran juga akan baik. Seorang pendidik juga sangat mempengaruhi kegiatan pembelajaran sehingga pendidik diharuskan mampu mengelola kegiatan pembelajaran agar tujuan pembelajaran dapat tercapai dengan baik.

\section{Model Pembelajaran}

Di dalam pembelajaran terdapat beberapa istilah seperti model, metode, strategi, pendekatan, teknik dan taktik. Istilah model pembelajaran mempunyai makna yang lebih luas daripada metode, strategi, pendekatan, teknik dan taktik. Menurut Ruseffendi (dalam buku Hamdayama), istilah strategi, metode, pendekatan dan teknik telah didefinisikan sebagai berikut:

a. Strategi pembelajaran adalah seperangkat kebijaksanaan yang terpilih, yang telah dikaitkan dengan faktor yang menentukan warna atau strategi tersebut.

11 Miftahul Huda, Model-Model Pengajaran dan Pembelajaran, (Yogyakarta: Pustaka Pelajar, 2016). h. 6
Pengajaran dan Pembelajaran. (Yogyakarta: Pustaka
12 Ibid., h. 75 
b. Pendekatan pembelajaran adalah jalan atau arah yang ditempuh oleh guru atau peserta didik dalam mencapai tujuan pembelajaran dilihat bagaimana materi itu disajikan.

c. Metode pembelajaran adalah cara mengajar secara umum yang dapat diterapkan pada semua mata pelajaran.

d. Teknik mengajaradalahpenerapan secara khusus suatu metode pembelajaran yang telah disesuaikan dengan kemampuan dan kebiasaan guru, ketersediaan media pembelajaran serta kesiapan peserta didik. ${ }^{13}$

Sedangkan istilah yang terkait dalam strategi pembelajaran yang mempunyai kemiripan makna, Majid juga menjelaskannya sebagai berikut:

a. Model pembelajaran, adalah kerangka konseptual dan prosedur yang sistematik dalam mengorganisasikan pengalaman belajar untuk mencapai tujuan belajar tertentu, berfungai sebagai pedoman bagi perancang pengajaran serta para guru dalam merencanakan dan melaksanakan aktivitas belajar mengajar.

b. Pendekatan pembelajaran, adalah cara umum yang ditempuh guru dalam proses membelajarkan peserta didik.

c. Metode pembelajaran, merupakan penyajian efektif dari muatan/konten tertentu suatu mata pelajaran sedemikian rupa sehingga dapat

13 Miftahul Huda, Model-Model Pengajaran dan Pembelajaran. (Yogyakarta: Pustaka Pelajar,2015), h. 127-128

14 Abdul Majid, Strategi Pembelajaran. dimengerti dan dipahami dengan baik oleh peserta didik.

d. Teknik pembelajaran, dapat diartikan sebagai cara yang dilakukan seseorang dalam mengimplementasikan metode secara spesifik. Teknik pembelajaran juga dikaitkan dengan keterampilan yang berarti perilaku pembelajaran yang sangat spesifik.

e. Taktik pembelajaran, merupakan gaya seseorang dalam melaksanakan metode atau teknik pembelajaran tertentu yang sifatnya individual. ${ }^{14}$

Majid juga berpendapat bahwa strategi pembelajaran merupakan suatu rencana tindakan (rangkaian kegiatan) yang termasuk penggunaan metode dan pemanfaatan berbagai sumber daya atau kekuatan dalam pembelajaran ${ }^{15}$. Sugihartono pun mengungkapkan bahwa metode pembelajaran berarti cara yang dilakukan dalam proses pembelajaran sehingga dapat diperoleh hasil yang optimal. ${ }^{16}$ Sedangkan Hamdayama mengemukakan bahwa model pembelajaran adalah suatu pola atau langkah-langkah pembelajaran yang diterapkan agar tujuan atau kompetensi dari hasil belajar yang diharapkan akan cepat dapat dicapai dengan lebih efektif dan efisien. Model pembelajaran dapat diartikan sebagai suatu rencana atau pola yang digunakan dalam menyusun kurikulum, mengatur materi peserta didik, dan memberi petunjuk kepada

${ }^{15} \mathrm{Ibid}$. h. 14

16 Sugihartono, dkk, (Psikologi Pendidikan. Yogyakarta: UNY Press, 2013). h. 81 
pendidik dalam melakukan proses pembelajaran.

Meskipun makna istilah-istilah tersebut hampir mirip, akan tetapi pada dasarnya masing-masing istilah

tersebut mempunyai arti yang berbeda. Pendekatan pembelajaran diartikan sebagai sudut pandang pendidik dalam melaksanakan pembelajaran yang menjadi sumber atau acuan dalam menentukan strategi yang digunakan dalam proses pembelajaran. Menurut Alwi pendekatan pembelajaran dibagi menjadi dua yaitu pendekatan yang berorientasi atau berpusat pada peserta didik (student center approach) dan pendekatan yang berorientasi atau berpusat pada guru (teacher center approach)

\section{a. Pembelajaran Berbasis Masalah (Problem Based Learning Methods)}

Model problem based learning juga biasa disebut dengan model pembelajaran berbasis masalah. Menurut Darmadi pembelajaran berbasis masalah merupakan sebuah pendekatan pembelajaran yang menyajikan masalah kontekstual sehingga merangsang peserta didik untuk belajar. Didalam kelas yang menerapkan model pembelajaran berbasis masalah, peserta didik bekerja dalam tim untuk memecahkan masalah dunia nyata. Masalah yang diberikan pada peserta didik ini digunakan untuk mengikat rasa ingin tahu pada pembelajaran yang dipelajari. Pembelajaran problem based learning didorong oleh tantangan, masalah nyata, dan peserta didik bekerja dalam kelompok kolaborasi kecil. Peserta didik didorong untuk bertanggungjawab terhadap kelompoknya dan mengorganisir proses pembelajaran dengan bantuan instruktur atau guru.

\section{Tujuan Pembelajaran Berbasis Masalah}

Pembelajaran berbasis masalah tidak dirancang untuk membantu guru memberikan informasi sebanyakbanyaknya kepada siswa seperti pada pembelajaran langsung dan ceramah, tetapi pembelajaran berbasis masalah dikembangkan untuk membantu siswa mengembangkan kemampuan berpikir, mengembangkan kemampuan memecahan masalah, keterampilan intelektual, dan menjadi siswa yang mandiri. ${ }^{17}$ Sedangkang karakteristik Pembelajaran berbasis masalah adalah sebagai berikut:

1. Pembelajaran berbasis masalah merupakan aktivitas pembelajaran, artinya dalam implementasinya pembelajaran berbasis masalah adalah sejumlah kegiatan yang harus dilakukan siswa. Pembelajaran berbasis masalah tidak mengharapkan siswa hanya sekedar mendengarkan, mencatat, kemudian menghafal materi pelajaran, akan tetapi melalui pembelajaran berbasis masalah siswa aktif berpikir, berkomunikasi, mencari dan
17 Trianto, Model-Model Pembelajaran Inovatif Berorientasi Konstruktivistik, (Jakarta: Prestasi Pustaka, 2007), h. 69-70 
mengolah data,dan akirnya menyimpulkan.

2. Aktivitas pembelajaran diarahkan untuk menyelesakan masalah. Pembelajaran berbasis masalah menempatkan masalah sebagai kata kunci dari proses pembelajaran.

3. Pemecahan masalah dilakukan dengan mengunaan pendekatan berpikir secara ilmiah. Berpikir dengan mengunakan metode ilmiah adalah proses berpikir deduktif dan induktif. Proses berpikir ini dilakukan secara sistematis dan empiris. Sistematis artinya berpikir ilmiah dilakukan melalui tahapan-tahapan tertentu, sedangkan empiris artinya proses penyelesaian masalah didasarkan pada data dan fakta yang jelas.

Setiap model pembelajaran mempunyai karakteristik masingmasing, hal inilah yang membedakan model pembelajaran yang satu dengan model pembelajaran yang lainnya. Sedangkan Trianto berpendapat bahwa karakteristik model pembelajaran problem based learning yaitu: (1) adanya pengajuan pertanyaan atau masalah; (2) berfokus pada keterkaitan antar disiplin; (3) penyelidikan autentik; (4) menghasilkan produk atau karya dan mempresentasikannya; dan (5) kerja sama. ${ }^{18}$

\section{Hasil Penelian}

Penelitian ini dilaksanakan di MIN 2 Kediri pada Pembelajaran Tematik tema 2 "Selalu Berhemat Energi" sub tema "Energi Alternatif" kelas IVD. Berdasarkan pada kegiatan pra tindakan yang telah dilakukan menunjukkan bahwa terdapat permasalahan yaitu rendahnya keaktifan peserta didik selama mengikuti kegiatan pembelajaran, sehingga hasil belajar peserta didik menjadi kurang maksimal. Data nilai ulangan harian Kelas 4D MIN 2 Kediri pada Pembelajaran Tematik tema Selalu Berhemat Energi, menunjukkan bahwa jumlah peserta didik yang mampu mencapai KKM hanya sebesar 65,71\% dari 35 peserta didik. Proses pembelajaran di dalam kelas cenderung monoton dan bersifat satu arah, dikarenakan bergantung pada guru. Sehingga peserta didik akan mudah bosan dan tidak bisa mengikuti pembelajaran dengan baik. Untuk mengatasi permasalahan tersebut, maka diperlukan adanya variasi dalam penggunaan model pembelajaran agar bisa mendorong peserta didik untuk lebih berperan aktif di kelas. Model yangakan diterapkan oleh peneilti untuk mengatasi permasalahan tersebut adalah dengan menggunakan model Pembelajaran Problem Based Learning.

Dari penelitian yang telah dilaksanakan di MIN 2 Kediri Kleas IV D pada tanggal 27 Agustus 2019 untuk siklus I dan tanggal 4 September 2019 
untuk siklus II, dengan menerapkan model pembelajaran Problem Based Learning dan hasilnya mampu membuat peningkatan keaktifan dan hasil belajar peserta didik pada setiap siklusnya. Berikut ini akan dijelaskan tentang penerapan model pembelajaran Problem Based Learning untuk meningkatkan keaktifan dan hasil belajar yang telah dilakukan:

\section{Penerapan Metode Pembelajaran}

Berbasis Masalah (Problem Based Learning Methods) di MIN 2 Kediri.

Pada penelitian ini materi pelajaran yang diajarkan adalah Pembelajaran Tematik tema 2 Selalu Berhemat Energi. Hal ini karena kompetensi ini sedang diajarkan oleh guru pengampu. Pelaksanaan model pembelajaran Problem Based Learning telah dirancang sedemikian rupa dengan mempertimbangkan langkah langkah pada model pembelajaran Problem Based Learning. Proses pengamatan dari pelaksanaan model pembelajaran Problem Based Learning dilakukan oleh observer. Observer melakukan pengamatan terhadap proses pelaksanaan model pembelajaran Problem Based Learning berdasarkan pada lembar observasi yang telah dibuat oleh peneliti sebelumnya. Lembar observasi pelaksanaan model pembelajaran Problem Based Learning ini digunakan selama proses penelitian yang berlangsung sebanyak dua siklus. Pada siklus I, pelaksanaan model pembelajaran Problem Based Learning belum
Hal ini dikarenakan guru belum mampu mengalokasikan waktu dengan baik. Sehingga waktu pembelajaran melebihi waktu yang telah direncanakan. Sedangkan pada siklus II, model pembelajaran Problem Based Learning terlaksana dengan baik karena guru sudah mampu mengalokasikan waktu. Keberhasilan pelaksanaan model pembelajaran dikarenakan sebelum memulai penelitian, guru diarahkan kembali untuk memahami langkahlangkah yang harus dilakukan dalam model pembelajaran dan pengalokasian waktu pembelajaran sudah teroganisir dengan baik sehingga apabila terjadi kendala dalam proses pembelajaran dapat segera teratasi dengan baik. Maka dari itu, pelaksanaan model pembelajaran Problem Based Learning sudah terlaksana dengan baik.

Dari Pengamatan hasil belajar pada siklus I dapat disimpulkan bahwa 1) Guru belum mampu mengalokasikan waktu sesuai dengan rencana pelaksanaan pembelajaran. 2) Peserta didik belum terbiasa menggunakan model pembelajaran Problem Based Learning, sehingga dibutuhkan adaptasi selama mengikuti pembelajaran. Peserta didik masih banyak yang bingung dalam mengikuti langkah-langkah dalam model pembelajaran Problem Based Learning. 3) Peserta didik masih ragu dalam menanggapi permasalahan atau menjawab pertanyaan dan masih terdapat peserta didik yang melakukan aktivitas negatif pada saat pembelajaran berlangsung. 4) Keaktifan peserta didik 
pada siklus I menunjukkan bahwa jumlah aktivitas positif belum memenuhi kriteria, sedangkan aktivitas negatif sudah memenuhi kriteria yang telah direncanakan. Hal ini dikarenakan peserta didik masih banyak yang pasif pada saat diskusi maupun presentasi sehingga aktivitas postitif tidak berjalan dengan baik.

Hasil belajar peserta didik pada siklus I menunjukkan bahwa jumlah peserta didik yang mampu mencapai KKM adalah sebesar 71,42\% dari jumlah peserta didik. Jumlah peserta didik yang telah mencapai KKM seharusnya dapat mencapai kriteria indikator keberhasilan yaitu sebesar $75 \%$ dari jumlah peserta didik.Berdasarkan hasil refleksi pada siklus I dapat disimpulkan bahwa aktivitas positif peserta didik perlu ditingkatkan lagi, karena belum mencapai indikator keberhasilan. Sedangkan hasil belajar peserta didik masih dikatakan rendah karena peserta didik yang mampu mencapai KKM adalah sebesar $71,43 \%$ dan sisanya masih di bawah KKM. Sedangkan Dari data hasil pengamatan pelaksanaan model pembelajaran Problem Based Learning siklus II dapat diketahui bahwa guru sudah mampu mengalokasikan waktu dengan baik. Hal ini dikarenakan sebelum memulai pembelajaran, guru diarahkan kembali agar sesuai dengan rencana pelaksanaan pembelajaran. Dari hasil tersebut dapat dikatakan bahawa penerapan model pembelajaran problem based learning sudah dilaksanakan dengan baik.
Berdasarkan hasil observasi terhadap keaktifan peserta didik pada siklus II, diketahui bahwa peserta didik sudah menunjukkan respon positif walaupun masih ada sebagaian peserta didik yang menunjukkan respon negatif. Hasil observasi keaktifan peserta didik pada siklus II menunjukan bahwa aktivitas positif peserta didik sebesar $73,70 \%$ dan aktivitas negatif peserta didik sebesar $26,30 \%$. Aktivitas postitif terlihat terjadinya peningkatan dibandingkan dengan siklus I. Pada siklus II peserta didik sudah mulai berani untuk menanggapi Pertanyaan ataupun menambahkan pendapatnya. Peningkatan aktivitas positif dan penurunan aktivitas negatif ini terjadi karena peserta didik sudah mulai paham dengan model pembelajaran Problem Based Learning yang telah dilakukan. Pengelolaan waktu yang dilakukan oleh guru juga sudah baik sehingga waktu tidak terbuang siasia.

Adapun nilai rata- rata kelas pada siklus II sebanyak 80,7. Hal ini menunjukkan bahwa terjadinya peningkatan nilai rata-rata kelas antara siklus I dengan siklus II yaitu sebesar 17,15 . Terdapat 31 peserta didik yang sudah mencapai batas KKM dengan nilai $\geq 75$. Berikut tabel Peningkatan Hasil Belajar Siswa Kelas 4D MIN 2 Kediri Tiap Siklus: 


\begin{tabular}{|c|c|c|c|c|}
\hline No & Aspek & $\begin{array}{l}\text { Pra } \\
\text { Siklus }\end{array}$ & $\begin{array}{c}\text { Siklus } \\
1\end{array}$ & Siklus 2 \\
\hline 1 & Nilai rata-rata kelas & 71,8 & 74,9 & 80,7 \\
\hline 2 & Nilai tertinggi & 87 & 90 & 96 \\
\hline 3 & Nilai terendah & 60 & 65 & 70 \\
\hline 4 & $\begin{array}{l}\text { Jumlah peserta didik yang } \\
\text { tuntas }\end{array}$ & 23 & 25 & 31 \\
\hline 5 & $\begin{array}{l}\text { Jumlah peserta didik yang } \\
\text { belum tuntas }\end{array}$ & 12 & 10 & 4 \\
\hline 6 & Presentase ketuntasan kelas & 65,71 & 71,42 & 88,57 \\
\hline 7 & $\begin{array}{l}\text { Presentase ketidaktuntasan } \\
\text { kelas }\end{array}$ & 34,29 & 28,58 & 11,43 \\
\hline
\end{tabular}

Dari tabel Presentase ketuntasan kelas pada siklus II sebesar 88,57\%, dengan ini dapat terlihat terjadinya peningkatan ketuntasan kelas dibandingkan pada siklus I yang hanya sebesar $71,43 \%$ dan pra siklus sebesar $65,71 \%$. Jadi hasil belajar peserta didik pada siklus II dapat dikatakan baik karena jumlah ketuntasan kelas sudah memenuhi kriteria indikator keberhasilan.

Faktor pendukung dalam melaksanakan Metode Pembelajaran Berbasis Masalah (Problem Based Learning Methods) di MIN 2 Kediri khususnya dikelas 4D

1. Guru mengikuti tahapan tahapan dalam melaksanakan Problem Pembelajaran Berbasis Masalah dengan baik sehingga pelaksanaan PBL bias berjalan dengan lancer.

2. Peserta didik memiliki minat dalam meyelesaikan masalah dan mau mengikuti tahapan tahapan dalam pelaksanaan metode pembelajaran berbasis masalah.

3. Peserta didik mau untuk menanyakan kesulitan yang dihadapi saat mengikuti pembelajaran serta menanggapi permasalahan atau menjawab pertanyaan.

4. Peserta didik mulai meminimalkan aktifitas negative karena model pembelajaran yang tidak monoton

5. Pengelolaan waktu yang dilakukan guru mulai maksimal sesuai dengan tahapan yang diinginkan, dan guru memberi batasan waktu pada saat pelaksanaan diskusi sehingga pembahasan bias maksimal.

\section{Penerapan Metode Pembelajaran}

Berbasis Masalah (Problem Based Learning Methods) di MIN 2 Kediri khususnya dikelas $4 \mathrm{D}$

1. Dalam pembelajaran guru sudah melakukan tahapan-tahapan pembelajaran dari model PBL tersebut menuntut siswa untuk berpikir high level. Dengan demikian penerapan model Problem Based Learning (PBL) dapa menumbuhkembangkan Higher Order Thinking Skill (HOTS) siswa Sekolah Dasar.

2. Pelaksanaan Problem Based Learning menuntuk aspek kemampuan 
berpikir tingkat tinggi atau HOTS antara lain menganalisis, mengevaluasi, dan mengkreasi. Semua aspek tersebut menjadi bagian dari sintaks pembelajaran model PBL. Model PBL diterapkan sesuai dengan pandangan konstruktivis yang menekankan pada kebutuhan siswa untuk melakukan penyelidikan terhadap lingkungannya dan membangun pengetahuan yang bermakna secara pribadi. Sintaks pembelajaran dengan menggunakan model PBL yang dilaksanakan secara sitematis berpotensi dapat menumbuhkembangkan keterampi-lan berpikir tingkat tinggi (Higher Order Thinking Skill) siswa dalam

menyelesaikan masalah dan sekaligus dapat memehami pengetahuan yang sesuai dengan kompetensi dasar tertentu. Hal itulah yang menjadikan siswa memiliki kemampuan berpikir tingkat tinggi, karena mereka tidak hanya mendengarkan penjelasanpenjelasan dari guru melainkan menggali pengetahuan dan ketrampilannya sendiri.

3. Pelaksanaan dan keberhasilan pendekatan pembelajaran melalui pemecahan masalah membutuhkan cukup waktu untuk persiapan sehingga tantangan bagi guru untuk selalu mempersiapkan waktu yang cukup lama

4. Guru sudah memotivasi peserta didik yang tidak memiliki minat atau tidak memiliki kepercayaan sehingga mereka tidak malu dan ragu untuk menanyakan kesulitan yang dihadapi saat mengikuti pembelajaran serta menanggapi permasalahan atau menjawab pertanyaan dan tidak terdapat peserta didik yang melakukan aktivitas negatif pada saat pembelajaran berlangsung

5. Guru kelas melatih peserta didik untuk terbiasa presentasi di depan kelas.

\section{Kesimpulan}

Berdasarkan hasil penelitian tindakan kelas yang dilaksanakan pada pra tindakan, siklus 1 dan siklus II dapat disimpulkan bahwa:

1. Implementasi pembelajaran Problem Based Learning dapat meningkatkan hasil belajar peserta didik untuk Pembelajaran Tematik Kelas IVD MIN 2 Kediri Tema 2 Selalu Hemat Energi dengan hasil penelitian menunjukkan bahwa aktivitas positif peserta didik sudah mencapai indikator keberhasilan dengan Presentase ketuntasan kelas mengalami peningkatan dari pra tindakan hanya $65,71 \%$ dengan nilai rata-rata 71,8 sedangkan pada siklus I ketuntasan belajar meningkat menjadi $71,42 \%$ dengan nilai rata-rata 74,9 . Jadi ada peningkatan sebanyak 5,71. Sedangkan pada siklus II ketuntasan belajar mencapai sebesar $88,57 \%$ dengan nilai rata-rata kelas 80,7 dan ada peningkatan dari sikus I pada siklus II sebanyak 17,15. Dengan ini dapat terlihat terjadinya peningkatan ketuntasan kelas sebanyak 22,86\% dari pra tindakan sampai siklus II 
sudah memenuhi kriteria indikator keberhasilan yaitu sebesar lebih dari $75 \%$ jumlah peserta didik. Ini menunjukkan bahwa pembelajaran Problem Based Learning dapat meningkatkan hasil belajar peserta didik untuk Pembelajaran Tematik Kelas IVD MIN 2 Kediri Tema 2 Selalu Hemat Energi.

2. FaKtor yang mendukung dalam pembelajaran berbasis masalah di MIN 2 Kediri adalah adanya kemauan dari guru kelas untuk melaksanakana tahapan tahapan dari PBL, antusias dari peserta didik untuk melaksanakan model model pembelajaran, kelas yang paralel yang memungkinkan guru kelas untuk saling berdiskusi dalam melaksanakan model pembelajaran dan dukungan dari wali murid.

\section{Daftar Pustaka}

Arikunto, Suharsimi. Prosedur Penelitian Suatu Pendekatan Praktik. Jakarta: Rineka Cipta, 2010

Darmadi, Pengembangan Model dan Metode Pembelajaran dalam Dinamika Belajar Peserta didik., Yogyakarta: Deepublish, 2017

Fuad, A. Jauhar and Hamam, Teori Dan Praktik Penelitian Tindakan Kelas (PTK) Tulungagung: STAIN, 2012

Huda, Miftahul. Model-Model Pengajaran dan Pembelajaran. Yogyakarta: Pustaka Pelajar, 20151 Miftahul Huda, Model-Model Pengajaran dan Pembelajaran, Yogyakarta: Pustaka Pelajar, 2016
Majid, Abdul Starategi Pembelajaran, Bandung: PT Remaja Rosdakarya, 2013

Min Liu. (2005) Motivating Students Through Problem-based Learning. Diakses dari http://coporate.sullivan.edu. Pada tanggal 25 Agustus 2019,

Moleong. Lexi J. Metodologi Penelitian Kualitatif Bandung : Remaja Rosdakarya, 2014

Sugihartono, dkk, Psikologi Pendidikan. Yogyakarta: UNY Press, 2013

Sugiyono, Metode Penelitian Pendidikan Pendekatan Kuantitatif, Kualitatif, dan RED, Bandung: Alfabeta,2013

Suprihatiningrum, Jamil, Strategi Pembelajaran Teori \& Aplikasi. Yogyakarta: Ar Ruzz Media, 2016

Suryadi, Ace dan Budimansyah, Dasim. Paradigma Pembangunan Pendidikan Nasional : Konsep, Teori dan Aplikasi dalam Analisis Kebijakan Publik, Bandung: Widya Aksara Pers, 2009

Trianto, Model-Model Pembelajaran Inovatif Berorientasi Konstruktivistik Jakarta: Prestasi Pustaka, 2007

Trianto, Mendesain Model Pembelajaran Inovatif Progresif. (Jakarta: Kencana, 2009 